\title{
Primary Cortisol Resistance Associated with a Thermolabile Glucocorticoid Receptor in a Patient with Fatigue as the Only Symptom
}

\author{
M. Brönnegård, $¥$ S. Wemer,\$ and J.-Å. Gustafsson¥ \\ Departments of ${ }^{*}$ Pediatrics and $\ddagger$ Medical Nutrition, Karolinska Institute, Huddinge University Hospital, \\ S-141 86 Huddinge; §Department of Endocrinology, Karolinska Hospital, S-104 01 Stockholm, Sweden
}

\begin{abstract}
We have studied a woman with an apparent receptor-mediated resistance to cortisol on the basis of elevated 24-h mean plasma cortisol levels and increased urinary free cortisol. Plasma ACTH concentrations were normal but she was resistant to adrenal suppression by dexamethasone. No stigmata of Cushing's syndrome were seen. To study the proposed end-organ resistance to cortisol, we examined the glucocorticoid receptor (GR) in lymphocytes and in fibroblasts from this patient and from her son. Several molecular properties of the GR of lymphocytes from the patient were indistinguishable from that of normal control subjects. In thermolability assays, however, the patient's GR as well as her son's GR showed a striking heat sensitivity at $40^{\circ}$ and $45^{\circ} \mathrm{C}$ when compared with GR from normal persons. In addition, data from the thermolability assays correlated well with the lack at $45^{\circ} \mathrm{C}$ of dexamethasone-induced decrease in in vitro $\left.\mathbf{P}^{3} \mathbf{H}\right]$ thymidine incorporation into lymphocytes derived from both patients.
\end{abstract}

\section{Introduction}

Glucocorticoid resistance in humans, characterized by hypercortisolism without the features of Cushing's syndrome, was first described in 1976 by Vingerhoeds et al. (1) in a 50-yr-old man with advanced hypertension and hypokalemic alkalosis. Subsequent biochemical (2) and genetical (3) studies indicated that the patient suffered from a rare familial syndrome where the primary cortisol resistance was due to a glucocorticoid receptor $(\mathrm{GR})^{1}$ present at the normal concentration but with decreased affinity for cortisol.

In this report, we describe a woman with primary glucocorticoid resistance in whom the end-organ insensitivity to cortisol apparently is not due to a decreased concentration or ligand affinity of the receptor. However, the GR of the woman as well as of her son, who did not show so pronounced clinical symptoms as those of his mother, displayed an increased thermolability, a phenomenon also seen with androgen receptors from patients with the testicular feminization syndrome (4).

\section{Case report}

The patient was 46 yr old when she consulted her local hospital for symptoms of edema, red, swollen hands, and a pronounced fatigue. She had no previous history of disease. The menopause

Received for publication 4 April 1985 and in revised form 24 June 1986.

1. Abbreviations used in this paper: GR, glucocorticoid receptor; TA, triamcinolone acetonide.

J. Clin. Invest.

(c) The American Society for Clinical Investigation, Inc. 0021-9738/86/11/1270/09 \$1.00

Volume 78, November 1986, 1270-1278 had occurred 3 yr earlier. The patient's mother had also had an early menopause. The patient's seven younger sisters were healthy. Her father had died from a cerebral hemorrhage at the age of 61 yr. The patient's mother suffered from diabetes, hypertension, and cardiac insufficiency. The patient's only child, a son $29 \mathrm{yr}$ old, had had periods of inexplicable fatigue that had made him stay home from school and work.

The patient was a cleaning assistant who had worked halftime for the previous $10 \mathrm{yr}$ owing to a tendency to fatigue, in this case a symptom including an increased need of sleep and a feeling of chilliness and of feebleness. During the course of investigation the cutaneous changes and edema vanished when a recently introduced cleaning detergent was avoided. The physical examination revealed nothing pathological. Her weight was 48 $\mathrm{kg}$ over the past several years and her height $166 \mathrm{~cm}$. Her blood pressure was $100-105 / 60-65 \mathrm{mmHg}$, with no orthostatism. There were no indications of anorexia or mental depression. The findings of her complete blood count, electrolytes, erythrocyte sedimentation rate, serum $\mathrm{Fe}$, cholesterol, triglycerides, albumin, endogenous creatinine clearance, liver function tests, thyroid-stimulating hormone, triiodothyronine, thyroxine, prolactin, luteinizing hormone, follicle-stimulating hormone, and testosterone were all normal for her age.

Because of the patient's slim features, Addison's disease was suspected but three urinary 24-h cortisol values were found to be two- to four-fold increased. The patient was referred to the Department of Endocrinology, Karolinska Hospital, Stockholm to determine whether she had Cushing's syndrome.

Plain x-rays of the skull and pituitary fossa, cisternography, and $2 \mathrm{yr}$ later, computed tomography scanning of the pituitary region yielded normal results as did sonography and computed tomography scanning of the adrenals, pancreas, and liver. Skeletal $x$-rays showed no signs of osteoporosis.

Since the detection of hypercortisolism, the patient has been observed for 4 yr during which her clinical features (no stigmata of Cushing's syndrome and continuing complaints of chilliness and of fatigue) have not changed. She has continued to work half-time as a cleaner. The 24-h cortisol excretions have constantly been two- to fourfold increased during the periods when she has felt completely healthy as well as during periods of fatigue. Three 24-h urine samples from her son were collected for the determination of cortisol. The patient has not received a trial of glucocorticoid treatment in order to see whether her symptoms would improve.

\section{Methods}

In this study healthy blood donors were used as controls. In each control experiment, $100 \mathrm{ml}$ of peripheral blood was used from which the lymphocytes were isolated.

\section{Isolation of human lymphocytes}

Fresh blood was diluted with a balanced salt solution (14.3 mM Tris, $98 \mu \mathrm{M} \mathrm{MgCl}_{2}, 0.54 \mathrm{mM} \mathrm{KCl}, 5 \mu \mathrm{M} \mathrm{CaCl}_{2}, 126 \mathrm{mM} \mathrm{NaCl}$, and $5.6 \mathrm{nM}$ 
D-glucose, pH 7.4) and layered on a discontinuous Ficoll-Paque gradient (Pharmacia, Uppsala, Sweden) in siliconized 50-ml centrifuge tubes. After centrifugation at $400 \mathrm{~g}$ in a Beckman TJ6 centrifuge (Beckman Instruments, Inc., Palo Alto, CA) for $30 \mathrm{~min}$ at $18^{\circ} \mathrm{C}$, the layer containing lymphocytes was withdrawn. The lymphocytes were washed twice by resuspension in the balanced salt solution and centrifugation at $100 \mathrm{~g}$ for $10 \mathrm{~min}$ at $18^{\circ} \mathrm{C}$. More than $95 \%$ of the lymphocytes were viable as determined by the trypan blue exclusion test and counting in a hemocytometer (Bürker, Kebo Laboratory, Stockholm) $(5,6)$. Cells that were not used immediately were frozen and stored at $-70^{\circ} \mathrm{C}$.

\section{Preparation of cytosol}

In order to eliminate the influence of endogenous steroids in the Scatchard analysis we used the procedure described by Rosner and Polimeni (7). They showed that during $20 \mathrm{~h}$ at $0^{\circ} \mathrm{C}$, soluble enzymes in the cytosol almost completely metabolize cortisol to products which do not interfere with the receptor binding of $\left[6,7-{ }^{3} \mathrm{H}\right]$ triamcinolone acetonide $\left({ }^{3} \mathrm{H}-\mathrm{TA}\right.$ : specific activity $300 \mathrm{kBq} / \mathrm{mmol}$, Amersham Searle Corp., Amsterdam, the Netherlands). At the end of this time, specifically bound ${ }^{3} \mathrm{H}-\mathrm{TA}$ (see below) is a valid measure of the total receptor concentration. Lymphocytes isolated from fresh blood were kept in a medium (RPMI 1640) without serum, supplemented with L-glutamine ( $2 \mathrm{mM}$ ), bensyl-penicillin (400 $\mathrm{IU} / \mathrm{ml})$, and streptomycin $(0.2 \mathrm{mg} / \mathrm{ml})$, for $24 \mathrm{~h}$ at $0^{\circ} \mathrm{C}$. The lymphocyte suspension was then centrifuged and the pellet was stored at $-70^{\circ} \mathrm{C}$ until used for the preparation of cytosol.

Fibroblasts from established cell cultures (described below) growing in monolayers were kept in a medium (minimal essential medium) without serum, supplemented with L-glutamine $(2 \mathrm{mM})$, bensyl-penicillin $(400 \mathrm{IU} / \mathrm{ml})$, and streptomycin $(0.2 \mathrm{mg} / \mathrm{ml})$, for $24 \mathrm{~h}$ at $37^{\circ} \mathrm{C}$. The medium was then removed, the monolayers were rinsed, the cells were harvested with trypsin-EDTA, and the resulting cell suspension was centrifuged. The cell pellet was stored at $-70^{\circ} \mathrm{C}$ until used for the preparation of cytosol.

Human lymphocytes and fibroblasts stored at $-70^{\circ} \mathrm{C}$ were lysed by thawing at $4^{\circ} \mathrm{C}$. Cells were then homogenized in ice-cold ETG buffer (1 mM EDTA, $20 \mathrm{mM}$ Tris-HCl, pH 7.8, 10\% (wt/vol) glycerol, and 2 $\mathrm{mM}$ dithiothreitol) in an all-glass Dounce $B$ homogenizer using 20 manual strokes. The homogenates were centrifuged at $100,000 \mathrm{~g}$ for $30 \mathrm{~min}$ at $0^{\circ} \mathrm{C}$ in a Beckman type $50 \mathrm{SW}$ rotor (Beckman Instruments, Inc., Palo Alto, CA). The clear supernatants were used as cytosol. The cytosol was incubated with $100 \mathrm{nM}^{3} \mathrm{H}$-TA at $0^{\circ} \mathrm{C}$ for $4 \mathrm{~h}$ in all experiments except in the case of the Scatchard analysis, where the incubation period was $24 \mathrm{~h}$. A 200 -fold molar excess of unlabeled TA was used in order to determine specific (i.e., displaceable) binding.

\section{Whole cell binding}

The binding capacity of mononuclear leucocytes was determined by incubating lymphocytes with medium without serum for $24 \mathrm{~h}$ and then washing the cells twice with phosphate-buffered saline before adding various concentrations of ${ }^{3} \mathrm{H}$-TA in $2 \mathrm{ml}$ of medium without serum and with or without a 200 -fold molar excess of nonradioactive TA. Each incubation contained $10^{6} \mathrm{cells} / \mathrm{ml}$ medium and was performed at $37^{\circ} \mathrm{C}$ in a $5 \% \mathrm{CO}_{2}$ incubator for $90 \mathrm{~min}$. The medium was removed by centrifugation, the cells were washed twice with phosphate-buffered saline, and harvested on glass-fiber filter-papers for measurement of radioactivity. Binding capacity, expressed as number of binding sites per cell, and apparent dissociation constant were calculated according to Scatchard (8).

\section{Cell culture}

Fibroblasts were established from explants of skin. Punch biopsies, 4 $\mathrm{mm}$ diam, were taken from the patient and her son and from six controls. Fibroblast strains and cell cultures were established according to Ham (9).

\section{Monolayer binding}

Cells from stock flasks were dissociated with $0.05 \%$ trypsin-EDTA at room temperature for $5 \mathrm{~min}$ and seeded (day 0 ) at a concentration of 50,000 cells per $3 \mathrm{ml}$ of medium containing $10 \%$ (vol/vol) fetal calf serum, supplemented with L-glutamine ( $2 \mathrm{mM}$ ), bensyl-penicillin (400 $\mathrm{IU} / \mathrm{ml})$, and streptomycin $(0.2 \mathrm{mg} / \mathrm{ml})$, in each well of a 24-well plastic plate (Chemoferm Inc., Stockholm). On day 7 the monolayers were rinsed with $3 \mathrm{ml}$ of phosphate-buffered saline, and $3 \mathrm{ml}$ of fresh medium without serum was added. On day 8 the medium was removed, and the monolayers were rinsed twice with $3 \mathrm{ml}$ of medium without serum and then incubated with various concentrations of ${ }^{3} \mathrm{H}$-TA in medium without serum and with or without a 200 -fold molar excess of nonradioactive TA. This procedure allows measurement of maximum glucocorticoidbinding capacity of the cells in the absence of endogenous steroids. Incubations were performed at $37^{\circ} \mathrm{C}$ in a $5 \% \mathrm{CO}_{2}$ incubator for $90 \mathrm{~min}$. The medium was then removed, the monolayers were rinsed, and the cells were harvested with trypsin-EDTA, and finally collected on glassfiber filter-papers with a cell harvester for measurement of radioactivity. Binding capacity, expressed as number of binding sites per cell, and apparent dissociation constant were calculated according to Scatchard (8).

\section{Scatchard analysis}

For Scatchard analysis (8) the cytosol prepared from lymphocytes and from fibroblasts was incubated with increasing concentrations (3.1-50 $\mathrm{nM}$ ) of ${ }^{3} \mathrm{H}$-TA alone or in the presence of a 200 -fold molar excess of unlabeled TA. At the end of the incubation period, $20-24 \mathrm{~h}$ at $0-4^{\circ} \mathrm{C}$, aliquots of $10 \mu \mathrm{l}$ were taken for determination of total radioactivity. Bound and free steroid was separated by the addition of one third of the incubation volume of a suspension of dextran-coated charcoal (final concentration $1 \%(\mathrm{wt} / \mathrm{vol})$ charcoal and $0.1 \%(\mathrm{wt} / \mathrm{vol})$ dextran) (10). The mixture was left for $10 \mathrm{~min}$ at $0^{\circ} \mathrm{C}$ and then centrifuged at $400 \mathrm{~g}$ for 10 min. Specific binding was defined as the difference in bound radioactivity between samples containing labeled steroid only (total binding) and samples containing both labeled and excess unlabeled steroid (nonspecific binding).

\section{Isoelectric focusing in polyacrylamide gel}

As a further means to quantitate the GR we used isoelectric focusing in polyacrylamide gel according to Hansson et al. (6). Polyacrylamide gels for isoelectric focusing were prepared as described by Wrange (11). All samples were applied in acrylic glass frames and analyzed simultaneously. The isoelectric focusing was performed at a current of $20 \mathrm{~mA}$ and a voltage of $1,200 \mathrm{~V}$. The total running time was $90 \mathrm{~min}$. The gel strip corresponding to the sample was cut into $0.5-\mathrm{cm}$ slices and transferred to counting vials. After addition of $5 \mathrm{ml}$ of scintillator fluid to the vials, the radioactivity in the slices was extracted at $60^{\circ} \mathrm{C}$ for $45 \mathrm{~min}$, and the radioactivity was measured in a liquid scintillation counter. Hansson et al. (6) also demonstrated a better recovery of total steroid-receptor complexes if the isoelectric focusing was carried out after limited proteolysis of the receptor. In the present experiments trypsin $(81 \mathrm{U} / \mathrm{mg}$ of protein, i.e., $0.8 \mu \mathrm{g} /\left(A_{280}-A_{310}\right)$ unit, see below) was used (10) and the reaction was carried out for $30 \mathrm{~min}$ at $10^{\circ} \mathrm{C}$.

\section{Protein determination}

An estimation of the cytosolic protein concentration was obtained by expressing the difference in optical density at $280 \mathrm{~nm}$ and $310 \mathrm{~nm},\left(A_{280^{-}}\right.$ $A_{310}$ ). Protein was also determined according to Lowry et al. (12). Receptor concentrations were expressed as femtomoles per milligram of protein.

\section{DNA-cellulose chromatography}

DNA-cellulose was prepared as described by Alberts and Herrick (13). Cytosolic samples $(1 \mathrm{ml})$ were labeled for $4 \mathrm{~h}$ at $0^{\circ} \mathrm{C}$ using $100 \mathrm{nM}$ final concentration of ${ }^{3} \mathrm{H}$-TA. Labeled cytosol was treated with dextran-coated charcoal to remove unbound steroid (10) and activation of the steroidreceptor complex was performed by incubation at $25^{\circ} \mathrm{C}$ for $30 \mathrm{~min}$. The incubation mixture was cooled on ice and applied on a 1-ml DNAcellulose column. The column was incubated with the sample for 15 min and then washed with five to six column volumes of ETG buffer. The column was eluted with $5 \mathrm{ml}$ of ETG buffer containing $0.3 \mathrm{M} \mathrm{NaCl}$. Aliquots, $100 \mu \mathrm{l}$, were taken from each fraction and counted for radioactivity. 


\section{Gel filtration}

Gel filtration was carried out on Agarose A-1.5 (Bio-Rad Pharmacia, Uppsala). Samples of $3 \mathrm{ml}$ were applied on the column $(87 \times 1.5 \mathrm{~cm})$ and chromatographed at $10 \mathrm{~cm} / \mathrm{h}$ in ETG buffer; $0.15 \mathrm{M} \mathrm{KCl} ; 0.02 \%$ (wt/vol) $\mathrm{NaN}_{3} ; 20 \mathrm{mM}$ molybdate. Molybdate was added to the sample $30 \mathrm{~min}$ after the addition of ${ }^{3} \mathrm{H}-\mathrm{TA}$ and $1 \mathrm{~h}$ before application to the column. The column was calibrated using the following proteins: horse spleen ferritin, ${ }^{14} \mathrm{C}$-methylated bovine serum albumin, ${ }^{14} \mathrm{C}$-methylated catalase, and ${ }^{14} \mathrm{C}$-methylated whale skeletal muscle myoglobin. The Stokes radii of these proteins are $6.15,3.59,5.20$, and $2.01 \mathrm{~nm}(14,15)$, respectively.

\section{Hormone assays}

Serum cortisol (16), urinary free cortisol (17), ACTH (18), aldosterone (19), insulin (20), and C peptide (21) were determined by radioimmunoassays. Cortisol-binding globulin and sex hormone-binding globulin were determined by equilibrium dialysis (22). The urinary excretion of glucocorticoid precursors and metabolites was determined by high-pressure liquid chromatography (23).

\section{Assays for temperature stability of $G R$}

Whole cell assay. Fibroblasts were grown in monolayer cultures as described above. One day prior to the experiment the monolayers were rinsed with $2 \mathrm{ml}$ of phosphate-buffered saline and $3 \mathrm{ml}$ of fresh medium (minimal essential medium) without serum were added. In experiments assessing binding at $40^{\circ}$ and $45^{\circ} \mathrm{C}$, the monolayers were preincubated at $40^{\circ}$ or $45^{\circ} \mathrm{C}$ for $60 \mathrm{~min}$ in medium without serum. The medium was then removed, and medium containing $100 \mathrm{nM}{ }^{3} \mathrm{H}-\mathrm{TA} \pm$ a 200 -fold molar excess of unlabeled TA (warmed to indicated temperatures) was added. The monolayers were then incubated for $60 \mathrm{~min}$ in the $\mathrm{CO}_{2}$ incubator at $40^{\circ}$ or $45^{\circ} \mathrm{C}$, respectively. In experiments assessing binding at $30^{\circ}$ and $35^{\circ} \mathrm{C}$, medium with ${ }^{3} \mathrm{H}-\mathrm{TA} \pm$ a 200 -fold molar excess of unlabeled TA (warmed to $30^{\circ}$ or $35^{\circ} \mathrm{C}$ ) was added to the monolayers, and the monolayers were incubated in a $\mathrm{CO}_{2}$ incubator at $30^{\circ}$ or $35^{\circ}$ for $60 \mathrm{~min}$. After incubation at the indicated temperatures, the medium was removed, the monolayers were rinsed twice, and the cells were harvested with trypsin-EDTA, then centrifuged and homogenized before aliquots were taken for measurement of radioactivity and protein. Binding was expressed as number of specific binding sites per milligram protein. There was no detectable metabolism of ${ }^{3} \mathrm{H}-\mathrm{TA}$ after warming of the incubation mixture to $45^{\circ} \mathrm{C}$ as assessed by thin-layer chromatography.

Cytosolic assay. After homogenization and centrifugation of a suspension of lymphocytes or fibroblasts, the supernatant (i.e., cytosol) was removed and used for binding assay. Binding was performed at $4^{\circ} \mathrm{C}$ for $30 \mathrm{~min}$, using $100 \mathrm{nM}{ }^{3} \mathrm{H}-\mathrm{TA} \pm$ a 200 -fold molar excess of unlabeled TA. Prior to incubation of cytosol at higher temperatures the samples were treated with dextran-coated charcoal in order to remove free steroid, as described in the Scatchard analysis above. The incubations were then continued for $60 \mathrm{~min}$ at $25^{\circ}, 30^{\circ}, 35^{\circ}, 40^{\circ}$, and $45^{\circ} \mathrm{C}$, respectively. After $90 \mathrm{~min}$ the incubations were terminated and the cytosol treated with one-third volume of dextran-coated charcoal (cf. above). Specific binding was determined and expressed as femtomoles of ${ }^{3} \mathrm{H}$-TA bound per $\mathrm{mg}$ of cellular protein.

\section{Thymidine incorporation}

In vitro sensitivity of cells to glucocorticoids was measured by studying the effects of dexamethasone on incorporation of radiolabeled thymidine. Lymphocytes $\left(5 \times 10^{6} / \mathrm{ml}\right)$ were incubated in triplicate with or without $10^{-6} \mathrm{M}$ dexamethasone for $24 \mathrm{~h}$ at $37^{\circ} \mathrm{C}$. Radiolabeled thymidine ([methyl- $\left.{ }^{3} \mathrm{H}\right]$ thymidine, specific activity $2.9 \mathrm{TBq} / \mathrm{mmol}$, Amersham International, Amersham, Buckinghamshire, England; final concentration $2 \mathrm{kBq}\left[\right.$ methyl $\left.-{ }^{3} \mathrm{H}\right]$ thymidine/ml) was then added and the incubation was continued for $6 \mathrm{~h}$ at indicated temperatures. The cells were harvested on glass-fiber filter-paper, and isotope incorporation was determined by liquid scintillation counting. Results from in vitro sensitivity studies were expressed as percent change of cellular isotope incorporation after steroid treatment.

\section{Results}

Glucocorticoid tests. Diurnal serum cortisol, which was analyzed on three occasions, showed slightly elevated levels and a blunted rhythm (Fig. 1 a). In February 1982, determination of diurnal plasma ACTH concomitantly with serum cortisol gave the values $6,4,4,2,3$, and $20 \mathrm{pmol} /$ liter, respectively; these figures are normal when compared with the reference ACTH value at 6 a.m., $30 \pm 26 \mathrm{pmol} / \mathrm{liter}$. Sporadic plasma ACTH analyzed concomitantly with serum cortisol at 8 a.m. on four occasions showed ACTH levels ranging between 8 and $38 \mathrm{pmol} /$ liter with serum cortisol ranging between 550 and $780 \mathrm{nmol} /$ liter (reference value $80-550 \mathrm{nmol} /$ liter). $1 \mathrm{nmol}$ cortisol/liter was equal to 3.62 $\mu \mathrm{g}$ cortisol/100 ml (the molecular weight for cortisol is 362,500 ).

Cortisol-binding globulin was $691 \mathrm{nmol} /$ liter, corresponding to upper normal range levels for young women (22). Sex hormone-binding globulin was $102 \mathrm{nmol} /$ liter (reference value 67$137 \mathrm{nmol} /$ liter).

The combined dexamethasone suppression (1 mg orally)/ ACTH stimulation (25 IU i.v.) test showed decreased cortisol suppression and normal cortisol increments (Fig. $1 b$ ).

The low- and high-dose oral dexamethasone suppression test, illustrated in Table I, showed decreased cortisol inhibition to exogenous glucocorticoids (24).

The metyrapone administration $(750 \mathrm{mg} \times 6 / 24 \mathrm{~h})$ test provoked a fourfold increment of basal Porter-Silber chromogens from 8,7 , and $8 \mathrm{mg} / \mathrm{d}$ (reference value $3-10 \mathrm{mg} / \mathrm{d}$ ) to $33 \mathrm{mg} / \mathrm{d}$ on the day of metyrapone administration, $25 \mathrm{mg} / \mathrm{d}$ on day 1 , and $13 \mathrm{mg} / \mathrm{d}$ on day 2 after metyrapone administration. The response indicated intact corticotropin-releasing hormone and ACTH reactivity and slightly hyperreactive adrenal glands (24).

Oral glucose loading. The oral glucose load showed normal fasting glucose levels and a normal postprandial pattern, the lowest glucose level being $2.4 \mathrm{mmol} / \mathrm{liter}$ at $210 \mathrm{~min}$. Concomitant analysis of plasma insulin and $\mathrm{C}$ peptide showed normal fasting levels and the expected rises after oral glucose challenge; $\mathrm{C}$ peptide and insulin levels were $0.4 \mathrm{pmol} / \mathrm{ml}$ (reference value $0.18-0.63 \mathrm{pmol} / \mathrm{ml}$ ) and $8 \mu \mathrm{U} / \mathrm{ml}$ (reference value $19.6 \pm 9.8 \mu \mathrm{U} /$ $\mathrm{ml}$ ), respectively, under basal conditions, $2.6 \mathrm{pmol} / \mathrm{ml}$ and 72 $\mu \mathrm{U} / \mathrm{ml}$ at $30 \mathrm{~min}$, and $3.2 \mathrm{pmol} / \mathrm{ml}$ and $126 \mu \mathrm{U} / \mathrm{ml}$ at $60 \mathrm{~min}$. Hence, there were no signs either of decreased sensitivity to insulin as seen in true hypercortisolism or increased sensitivity to insulin, which should have been expected in a case of clinically overt cortisol resistance.

Mineralocorticoid axis. Diurnal plasma aldosterone was normal. Urinary aldosterone, serum and urinary sodium and potassium, and plasma renin in recumbent and upright positions were normal, as were serum bicarbonate and chlorides. There was on no occasion any tendency to hypokalemia or alkalosis. These observations are not in accordance with the case previously described by Vingerhoeds et al. (1) where the patient suffered from hypertension as well as from severe hypokalemia.

Excretion of urinary steroids. Analysis was made when total 24-h cortisol was $765 \mathrm{nmol} / \mathrm{d}$ (reference value $83-300 \mathrm{nmol} / \mathrm{d}$ ). The steroid excretory profile was normal; the 24-h excretion of androsterone was $3.7 \mu \mathrm{mol}$, etiocholanolone $5.9 \mu \mathrm{mol}$, dehydroepiandrosterone $2.1 \mu \mathrm{mol}, 11$-oxo-etiocholanolone $2.7 \mu \mathrm{mol}$, $11 \beta$-hydroxyandrosterone $+17 \alpha$-hydroxypregnanolone 3.9 $\mu \mathrm{mol}, 11 \beta$-hydroxyetiocholanolone $4.6 \mu \mathrm{mol}$, pregnanediol 2.1 $\mu \mathrm{mol}$, and pregnanetriol $0.8 \mu \mathrm{mol}$. The excretion of the cortisol metabolites tetrahydrocortisone, tetrahydrocortisol, allotetrahydrocortisol, $\alpha$-cortolone, $\beta$-cortolone, $\beta$-cortol, and $\alpha$-cortol 

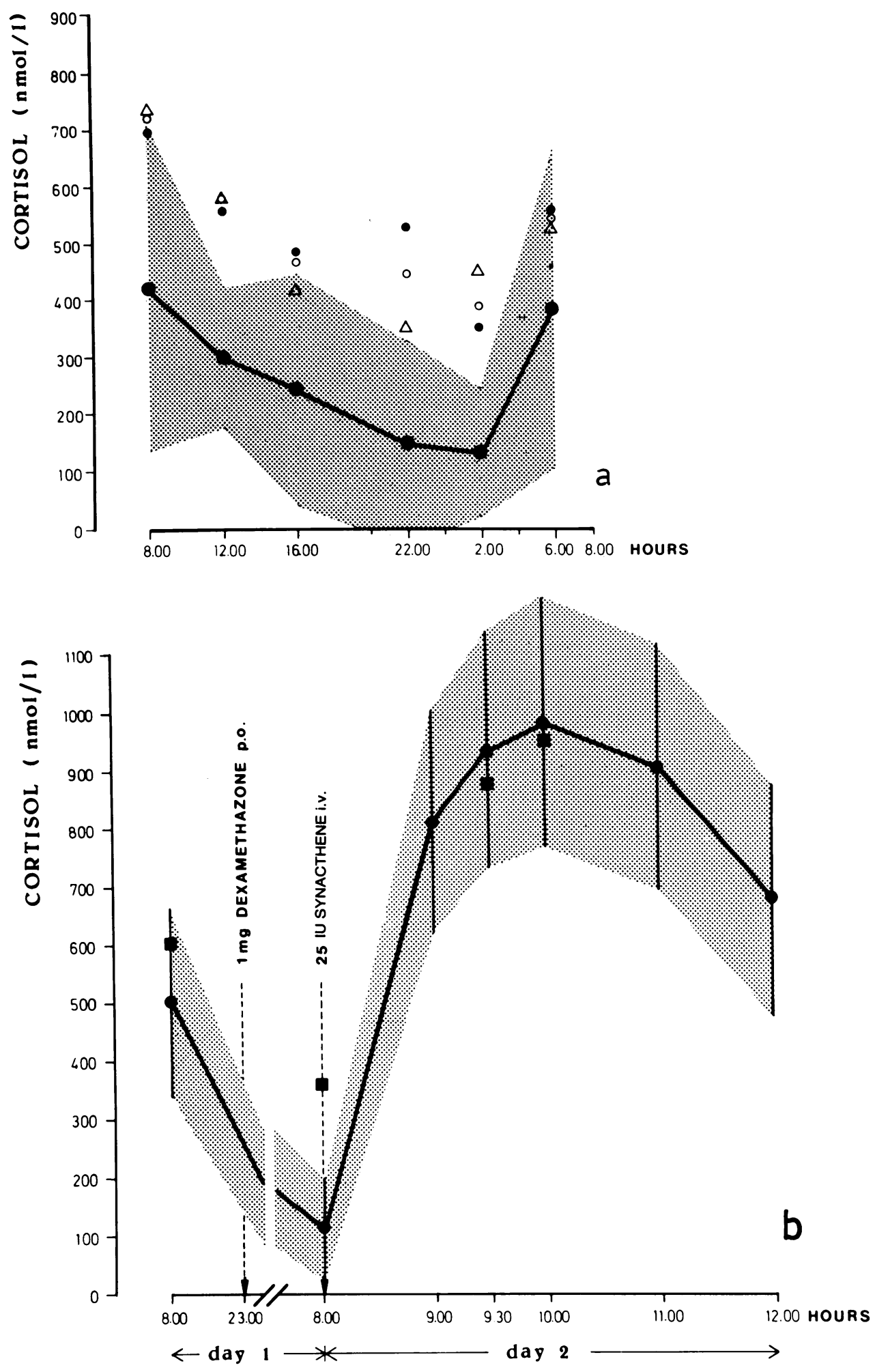

Figure 1. (a) Diurnal serum cortisol in a woman with increased urinary excretion of cortisol without clinical signs of hypercortisolism. Cortisol levels were analyzed in (O) February and (๑) June 1982 and in $(\Delta)$ February 1984. Shaded area denotes serum cortisol (mean $\pm 2 \mathrm{SD}$; $n=28)$ in healthy controls. (b) Serum cortisol before and $9 \mathrm{~h}$ after $1 \mathrm{mg}$ of dexamethasone and 1.5 and $2 \mathrm{~h}$ after an intravenous injection of $25 \mathrm{IU}$ of synthetic ACTH (1-24 Synacthen). Shaded area denotes normal response (mean \pm 2 SD; $n=32$ ). (ם) Patient. Abbreviation: 1, liter.

were within the normal total range, $20.2 \mu \mathrm{mol} / \mathrm{d}$. However, the ratios between different cortisol metabolites were similar to those seen in hypercortisolism due to Cushing's disease (22); tetrahydrocortisol/tetrahydrocortisone was 1.2 (reference $<1$ ) and tetrahydrocortisol/allotetrahydrocortisol was 4.7 (reference $<4.5$ ).

Studies on the patient's son. One of three urinary 24-h cortisol values was increased, $381 \mathrm{nmol} / \mathrm{d}$ (reference value for men 83$300 \mathrm{nmol} / \mathrm{d}$ ). The results of the complete blood count, electro- lytes, liver and renal function tests, serum cholesterol, and triglycerides were within normal limits. He was asymptomatic with no stigmata of Cushing's syndrome.

Scatchard analysis. The specific binding of ${ }^{3} \mathrm{H}$-TA in cytosol from the patient's lymphocytes as well as from control lymphocytes is shown in Fig. 2, where the inset shows data replotted according to Scatchard (8). The straight lines obtained $(r=-0.80$ and $r=-0.82$ ) suggest that, under our assay conditions, ${ }^{3} \mathrm{H}-\mathrm{TA}$ 
Table I. Serum and Urinary Cortisol during Peroral Suppression Test, with Low and High Doses of Dexamethasone

\begin{tabular}{|c|c|c|c|c|c|c|c|}
\hline Day & 1 & 2 & 3 & 6 & 7 & 10 & 11 \\
\hline Dexamethasone $0.5 \mathrm{mg} \times 4$, day $4-7$ & & & & + & + & & \\
\hline Dexamethasone $2 \mathrm{mg} \times 4$, day $8-11$ & & & & & & + & + \\
\hline Serum cortisol, nmol/liter & & 725 & & 365 & 442 & 40 & 30 \\
\hline Urinary cortisol, $n$ mol/liter & 604 & 765 & 590 & 132 & 153 & 36 & 48 \\
\hline
\end{tabular}

binds to a single class of receptor sites of uniform ligand affinity, both in lymphocytes from the patient and in lymphocytes from the controls. The total number of binding sites per cell was 1,600

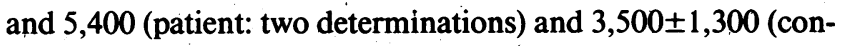
trols: $n=8$ ). The dissociation constants were 4.2 and 3.9 (patient: two determinations) and 4.1 $\pm 2.0 \mathrm{nM}$ (controls: $n=8$ ). The son showed similar GR characteristics as assayed in lymphocytes. The total number of binding sites per cell was 2,000 and 1,500 (two determinations) and the dissociation constant was 4.5 and $5.3 \mathrm{nM}$ (two determinations). In addition, the binding capacity of cultured skin fibroblasts, expressed either as femtomoles per milligram of protein in cytosol or sites per cell $\left(R_{\mathrm{o}}\right)$ in whole cells did not reveal any differences between the two patients and the controls. In all cases, the total number of binding sites per cell was approximately 40,000 and the apparent dissociation constant $5.0 \mathrm{nM}$. The results from our studies on the characteristics of the GR from the patient, her son, and controls are summarized in Table II.

From these results it is obvious that no differences exist concerning receptor-ligand affinity or number of specific ligandbinding sites in lymphocytes or fibroblasts when comparing the two patients with the controls.

According to Lippman and Barr (25), no differences were seen between subpopulations of human mononuclear cells with regard to $K_{\mathrm{D}}$ values or number of specific glucocorticoid binding sites per cell. Therefore, the unfractionated lymphocytes isolated with Ficoll-Paque should contain a homogeneous pool of GR.

DNA-cellulose chromatography. The DNA-binding capacity of lymphocytic GR was studied using DNA-cellulose chromatography of thermally activated receptor (26). In order to elute

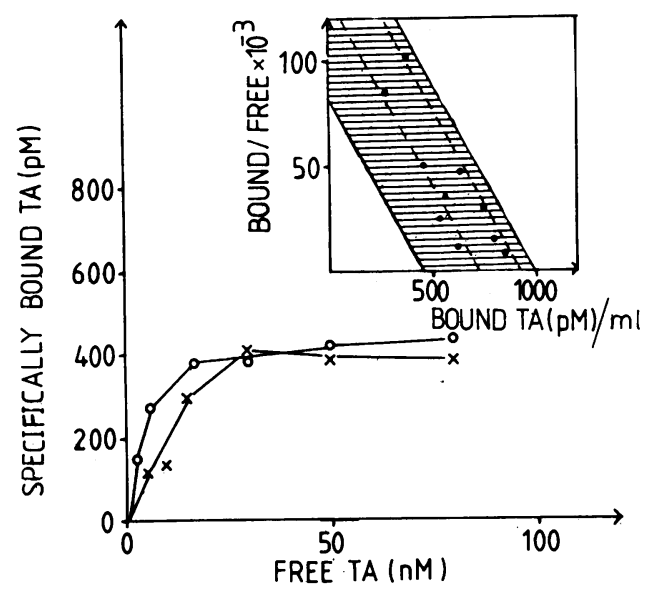

Figure 2. Binding of ${ }^{3} \mathrm{H}-\mathrm{TA}$ to cytoplasmic receptors from (0) the patient and from $(X)$ controls. Cytosol was incubated with various concentrations of ${ }^{3} \mathrm{H}-\mathrm{TA}$ as described in Methods. (Inset) Scatchard plot of the binding data. (๑) Patient (mean of three determinations of each concentration); shaded area denotes the range of the eight controls. both the 6- and 3.3-nm receptor forms, previously described for the rat liver GR and shown to elute at 0.17 and $0.25 \mathrm{M} \mathrm{NaCl}$, respectively (27), DNA-cellulose was first washed with five to six column volumes of ETG buffer, giving the flow-through containing nonactivated GR, and then eluted with $5 \mathrm{ml} \mathrm{ETG}$ buffer with $0.3 \mathrm{M} \mathrm{NaCl}$. No significant difference in total DNA-cellulose binding of activated lymphocytic GR from the patient as compared to the controls was found (Table III).

Gel filtration. In order to compare further the GR from the patient and controls, respectively, agarose filtration of molybdatestabilized cytosolic ligand-receptor complex was carried out. GR from human lymphocytes, particularly in its free form, is generally unstable in cytosol, probably due to a high concentration of proteolytic enzymes in this type of preparation (28). In order to stabilize the receptor during long chromatographic procedures, gel filtration was carried out in the presence of molybdate.

Table IV summarizes the results from the gel filtrations. The 8.1-nm nonactivated complex as well as the 5.1- and the 3.6nm complex were represented both in cytosol from the controls and in the cytosol from the patients. These results are in general accordance with findings previously reported by Sherman et al. $(28,29)$ on molybdate-stabilized GR in cytosolic preparations from a variety of tissues.

In conclusion, no difference in size between GR complexes from the patient and the controls, respectively, was found.

Temperature stability. In the cytosolic assay very low levels of specific ${ }^{3} \mathrm{H}$-TA binding, $2.2 \pm 1.9$ and $0.3 \pm 0.5 \mathrm{fmol} / \mathrm{mg}$ protein, respectively, were found at $40^{\circ}$ and $45^{\circ} \mathrm{C}$ in lymphocytes from the patient. In controls, on the other hand, the $95 \%$ confidence interval for specific binding at $40^{\circ} \mathrm{C}$ was $17.8-66.9 \mathrm{fmol} / \mathrm{mg}$ protein and at $45^{\circ} \mathrm{C} 16.1-22.7 \mathrm{fmol} / \mathrm{mg}$ protein (Fig. $3 \mathrm{c}$ ). A dramatic drop in specific ${ }^{3} \mathrm{H}$-TA binding in cytosolic samples from the patient occurred between $35^{\circ}$ and $40^{\circ} \mathrm{C}$. Incubations of cytosol from the patient and the controls respectively, at $0^{\circ} \mathrm{C}$ up to $35^{\circ} \mathrm{C}$ did not reveal any differences in specific binding of ${ }^{3} \mathrm{H}-\mathrm{TA}$.

Similar profiles of GR thermolability curves were observed for fibroblasts. In controls the $95 \%$ confidence interval for specific cytosolic binding at $40^{\circ} \mathrm{C}$ was $210-285 \mathrm{fmol} / \mathrm{mg}$ protein and at $45^{\circ} \mathrm{C} 95-135 \mathrm{fmol} / \mathrm{mg}$ protein (Fig. $3 \mathrm{a}$ ). The patient had an abnormally low ${ }^{3} \mathrm{H}$-TA-binding capacity at $40^{\circ}$ and $45^{\circ} \mathrm{C}$, $7.5 \pm 3.5 \mathrm{fmol} / \mathrm{mg}$ protein and undetectable binding, respectively. Even at $30^{\circ}$ and $35^{\circ} \mathrm{C}$, the patient showed lower specific ${ }^{3} \mathrm{H}$ TA binding than the controls. Her son also showed an abnormally low ${ }^{3} \mathrm{H}$-TA-binding capacity at these temperatures, $125 \pm 7$ $\mathrm{fmol} / \mathrm{mg}$ protein at $40^{\circ} \mathrm{C}$ and undetectable binding at $45^{\circ} \mathrm{C}$. At $30^{\circ} \mathrm{C}$, however, he still showed the same ${ }^{3} \mathrm{H}$-TA-binding capacity as the controls. Comparable results were obtained with the whole cell assay but in this case the specific binding of the son compared to that of the controls did not differ until the temperature was increased to $40^{\circ} \mathrm{C}$ (Fig. $3 \mathrm{~b}$ ). In controls, the $95 \%$ confidence 
Table II. Concentration and Ligand Affinity of GR in Patients and Controls

\begin{tabular}{|c|c|c|c|}
\hline & Mother* & Son* & Controls (mean \pm SD) \\
\hline \multicolumn{4}{|l|}{ Whole cells } \\
\hline \multicolumn{4}{|l|}{ Cultured skin fibroblasts } \\
\hline Binding capacity $\left(R_{\mathrm{o}}\right)$, sites per cell & 35,$000 ; 40,000$ & 25,$000 ; 35,000$ & $40,000 \pm 15,000(n=6)$ \\
\hline Apparent dissociation constant, $n M$ & $5.0 ; 3.5$ & $4.5 ; 8.0$ & $7.0 \pm 2.5(n=6)$ \\
\hline \multicolumn{4}{|l|}{ Mononuclear leukocytes } \\
\hline Binding capacity $\left(R_{\mathrm{o}}\right)$, sites per cell & 1,$600 ; 5,400$ & 2,$000 ; 1,500$ & $3,300 \pm 1,300(n=8)$ \\
\hline Apparent dissociation constant, $n M$ & $8.0 ; 5.3$ & $4.0 ; 4.5$ & $5.5 \pm 2.0(n=8)$ \\
\hline \multicolumn{4}{|l|}{ Cytosol } \\
\hline \multicolumn{4}{|l|}{ Cultured skin fibroblasts } \\
\hline $\begin{array}{l}\text { Binding capacity }\left(R_{\mathrm{o}}\right) \\
\mathrm{fmol} / \mathrm{mg} \text { protein }\end{array}$ & $\begin{array}{l}98 ; 100 \\
\quad(r=-0.90 ;-0.89)\end{array}$ & $\begin{array}{l}80 ; 65 \\
\quad(r=-0.93 ;-0.90)\end{array}$ & $120 \pm 30(r=-0.89 \pm 0.05)(n=6)$ \\
\hline Dissociation constant, $n M$ & $9.5 ; 8.3$ & $9.8 ; 7.4$ & $7.5 \pm 2.5(n=6)$ \\
\hline \multicolumn{4}{|l|}{ Mononuclear leukocytes } \\
\hline $\begin{array}{l}\text { Binding capacity }\left(R_{\mathrm{o}}\right) \\
\mathrm{fmol} / \mathrm{mg} \text { protein }\end{array}$ & $\begin{array}{l}110 ; 390 \\
\quad(r=-0.80 ;-0.82)\end{array}$ & $\begin{array}{l}190 ; 280 \\
\quad(r=-0.82 ;-0.90)\end{array}$ & $430 \pm 120(r=-0.89 \pm 0.03)(n=8)$ \\
\hline Dissociation constant, $n M$ & $4.2 ; 3.9$ & $5.3 ; 4.5$ & $4.1 \pm 2.0(n=8)$ \\
\hline
\end{tabular}

Preparation of cytosol and incubation of cells were carried out as described in Methods. Abbreviation: $r$, correlation coefficient of the Scatchard regression lines. * Results from two separate determinations.

interval for specific whole cell binding at $40^{\circ} \mathrm{C}$ was $65-85 \mathrm{fmol} /$ $\mathrm{mg}$ protein and at $45^{\circ} \mathrm{C} 10-20 \mathrm{fmol} / \mathrm{mg}$ protein. The patient had undetectable binding at $40^{\circ} \mathrm{C}$ as well as at $45^{\circ} \mathrm{C}$, whereas her son had a ${ }^{3} \mathrm{H}$-TA-binding capacity of $5 \pm 3 \mathrm{fmol} / \mathrm{mg}$ protein at $40^{\circ} \mathrm{C}$ and undetectable binding at $45^{\circ} \mathrm{C}$. Incubations of cytosol from fibroblasts and whole fibroblasts at $0^{\circ} \mathrm{C}$ up to $30^{\circ} \mathrm{C}$ did not reveal any differences in specific binding of ${ }^{3} \mathrm{H}$-TA between the two patients and the controls, respectively (data not shown).

In mixed cytosolic samples from a control and the two patients specific binding was detectable even at $45^{\circ} \mathrm{C}$, indicating that the disappearance of binding in samples from the patients at elevated temperatures was not due to the activation of proteases (Fig. $4 a$ and $b$ ). Furthermore, addition of protease inhibitors to cytosolic incubations did not alter the thermolability profiles of specific ${ }^{3} \mathrm{H}$-TA binding for any of the two patients (data not shown). We also investigated the effect of lowering the temperature used in the monolayer binding assay to $25^{\circ} \mathrm{C}$ after a preincubation at $45^{\circ} \mathrm{C}$ for $60 \mathrm{~min}$. In these experiments both patients showed a reversible decrease in specific binding at elevated temperature (data not shown). Taken together, these results indicate the presence of a thermolabile GR in cells from the

Table III. DNA-cellulose Chromatography of Thermally Activated Human Lymphocytic Glucocorticoid Receptor

\begin{tabular}{lll}
\hline & Flow-through & Retained \\
\hline & $\%$ & $\%$ \\
Patient $(n=2)$ & $86 ; 82$ & $13 ; 15$ \\
Control $(n=6)^{*}$ & $75 \pm 1.4$ & $19 \pm 1.2$ \\
\hline
\end{tabular}

The flow-through represents the fraction of the complex detected after washing the DNA-cellulose column with 5-6 vol of ETG buffer without salt. Recovery in percentage of totally applied complex. The retained ${ }^{3} \mathrm{H}-\mathrm{TA}$ receptor complex was eluted with $5 \mathrm{ml}$ of $0.3 \mathrm{M} \mathrm{NaCl}$ in ETG buffer. For further details, see text.

* All values represent mean $\pm S D$. patient as well as from her son. The defect is probably intrinsic in the receptor molecule and is not related to the cellular milieu.

Thymidine incorporation. The inhibition of $\left[{ }^{3} \mathrm{H}\right]$ thymidine incorporation in lymphocytes at $35^{\circ}, 37^{\circ}$, and $45^{\circ} \mathrm{C}$ was more pronounced in controls than in the two patients (Table V). At $45^{\circ} \mathrm{C}$, no inhibition was observed in either patient; these results are in agreement with the loss of specific ${ }^{3} \mathrm{H}$-TA binding at these temperatures in cells from the patients (cf. above).

\section{Discussion}

The patient under study showed an apparent end-organ insensitivity to cortisol. Despite signs of chronic endogenous hypercortisolism-increased serum and urinary cortisol, altered excretory profiles of cortisol metabolites, hyperreactive adrenal response after metyrapone administration, and decreased cortisol

Table IV. Stokes Radius $\left(R_{S}\right)^{*}$ of Molybdate-stabilized Glucocorticoid Receptor from the Patient and Controls, as Determined by Gel Filtration on Agarose A-1.5.

\begin{tabular}{ll}
\hline Patient $R_{s}(n=2)$ & Controls $R_{s}(n=5) \ddagger$ \\
\hline$n m$ & $n m$ \\
$8.1 ; 8.3$ & $8.1 \pm 0.2$ \\
$5.1 ; 5.3$ & $5.1 \pm 0.3$ \\
$3.6 ; 3.6$ & $3.7 \pm 0.2$
\end{tabular}

Cytosols were prepared from lymphocytes, as described in Methods, and gel filtration of the ${ }^{3} \mathrm{H}$-TA-labeled cytosols was carried out on Agarose A-1.5. Samples of $3 \mathrm{ml}$ were applied on the column and chromatographed at $10 \mathrm{~cm} / \mathrm{h}$ in ETG buffer; $0.15 \mathrm{M} \mathrm{KCl} ; 0.02 \%$ (wt/vol) $\mathrm{NaN}_{3} ; 20 \mathrm{mM}$ molybdate.

* Stokes radius $\left(R_{S}\right)$ as determined by agarose filtration and linear regression analysis of $\log R_{S}$ vs. distribution coefficient for the internal standards.

$\ddagger$ All values represent mean \pm SD. 

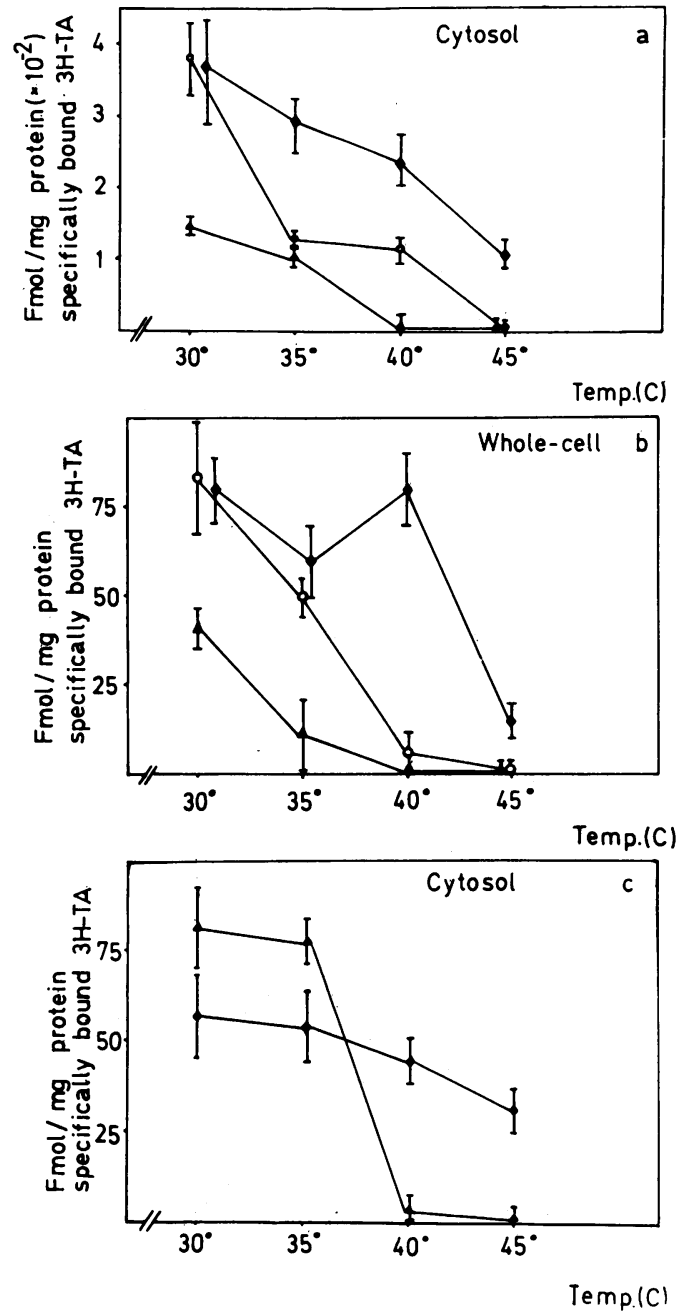

Figure 3. Effect of elevated temperature on specific binding of ${ }^{3} \mathrm{H}-\mathrm{TA}$ in lymphocytes and fibroblasts from $(\Delta)$ the patient, $(0)$ her son, and $(\bullet)$ controls. At each temperature specific ${ }^{3} \mathrm{H}$-TA-binding capacity was determined on triplicate aliquots of cytosol or wells of monolayers, as described in Methods, and the mean \pm SD was calculated from these three incubations. This procedure was repeated for each of the 10 controls and a total mean $\pm \mathrm{SD}$ was calculated for each temperature. For the patient and her son specific ${ }^{3} \mathrm{H}$-TA-binding capacity was determined in the same manner and repeated twice. (a) Cytosolic assayfibroblasts. (b) Whole cell assay-fibroblasts. (c) Cytosolic assay-lymphocytes.

inhibition by exogenous glucocorticoids-she lacked the classical features of Cushing's syndrome. In contrast, she had signs and symptoms reminiscent of Addison's disease, namely, low body weight, low blood pressure, and fatigue. There was no clear evidence of advanced adrenal hyperplasia: sonography and computed tomography scanning visualized adrenal glands of normal size. Diurnal plasma ACTH was within the normal range.

Thus, in this patient the peripheral insensitivity to cortisol was not associated with the secondary, ACTH-dependent increased secretion of mineralocorticoids found in the previously reported case (2) with very advanced cortisol resistance and with cortisol levels similar to those of our patient. This indicates the existence of subgroups of primary cortisol resistance with varying compensatory mechanisms. Because of the relatively small number of family members investigated (cf. Fig. 5) no pattern

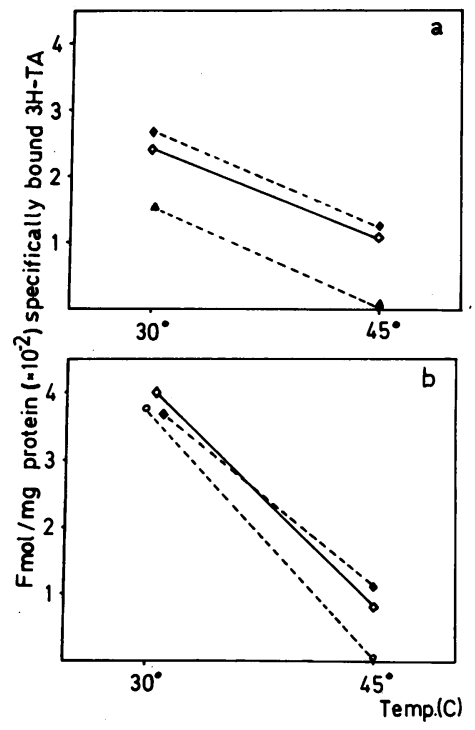

Figure 4. Analysis of proteolytic activity. Cytosol was prepared as described in Methods. $0.5 \mathrm{ml}$ of ${ }^{3} \mathrm{H}-\mathrm{TA}$-labeled cytosol from ( $\bullet$ ) a control was mixed at indicated temperatures with $0.5 \mathrm{ml}$ of unlabeled cytosol from $(\Delta)$ the mother or with $0.5 \mathrm{ml}$ of unlabeled cytosol from (o) the son. After incubation for $60 \mathrm{~min}$, the mixtures were treated with dextran-coated charcoal and centrifuged and aliqots were taken for measurement of radioactivity. Using the same cytosolic preparations, specific binding at $30^{\circ}$ and $45^{\circ} \mathrm{C}$ was determined by incubating $1 \mathrm{ml}$ of cytosol from each patient, as well as from the control, with $100 \mathrm{nM}$ ${ }^{3} \mathrm{H}-\mathrm{TA} \pm$ a 200 -fold molar excess of nonradioactive TA. The values represent the mean of two separate determinations and the specific ${ }^{3} \mathrm{H}$-TA-binding capacity after mixing the cytosol is indicated with a solid line ( $\diamond)$. (a) Mixing experiment (mother). (b) Mixing experiment (son).

Table V. Inhibition of $\left[{ }^{3} H\right]$ Thymidine Incorporation at Indicated Temperatures

\begin{tabular}{clll}
\hline Temperature & tdex & -dex & Percent change \\
\hline \multicolumn{3}{l}{$d p m / m g$ protein } & $d p m / m g$ protein \\
$15^{\circ} \mathrm{C}$ & & & \\
Controls & $280 \pm 20$ & $620 \pm 20$ & $55 \pm 10(n=6)$ \\
Mother* & $225 ; 330$ & $450 ; 660$ & $50 ; 50$ \\
Son* & $290 ; 255$ & $605 ; 510$ & $52 ; 50$ \\
$35^{\circ} \mathrm{C}$ & & & \\
Controls & $180 \pm 15$ & $600 \pm 30$ & $70 \pm 15(n=6)$ \\
Mother* & $340 ; 315$ & $610 ; 450$ & $45 ; 30$ \\
Son* & $290 ; 300$ & $485 ; 545$ & $40 ; 45$ \\
$37^{\circ} \mathrm{C}$ & & & \\
Controls & $210 \pm 25$ & $555 \pm 30$ & $65 \pm 10(n=6)$ \\
Mother* & $405 ; 390$ & $605 ; 590$ & $33 ; 34$ \\
Son & $350 ; 390$ & $620 ; 605$ & $43 ; 36$ \\
$45^{\circ} \mathrm{C}$ & & & \\
Controls & $280 \pm 30$ & $430 \pm 30$ & $35 \pm 10(n=6)$ \\
Mother* & $550 ; 485$ & $555 ; 480$ & $5 ; \mathrm{ND}$ \\
Son* & $395 ; 430$ & $405 ; 455$ & $2 ; 5$
\end{tabular}

Incubation of cells and determination of $\left[{ }^{3} \mathrm{H}\right]$ thymidine incorporation were carried out as described in Methods. Abbreviations: dex, dexamethasone; ND, no detectable inhibition.

* Results from two separate determinations. 


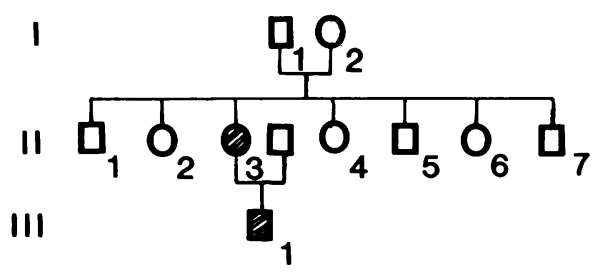

Figure 5. Family pedigree. The father $(I ; 1)$ of the patient $(I I ; 3)$ died at the age of 61 in a cerebral hemorrhage. The mother of the patient $(I ; 2)$ is suffering from hypertension, cardiac insufficiency, and diabetes mellitus. Three brothers and three sisters of the patient are all healthy with no known endocrinologic diseases. The son (III; I) of the patient has markedly elevated urinary free cortisol concentrations and shows the same tendency of fatigue as his mother.

of inheritance may be predicted at this stage. In the present case, a moderate increase in cortisol secretion was sufficient to maintain an adequate peripheral action of cortisol, as indicated by normal glucose, insulin, and C-peptide increments after an oral glucose load.

The presence of normal concentrations of cytosolic GR with normal ligand affinity in the patient's lymphocytes and fibroblasts was evidently not sufficient for a normal responsiveness to glucocorticoids. There are several steps after the initial binding of the steroid to the receptor that precede the phenotypic expression of the steroid action characteristic of a given cell type. Any of these biochemical events, including the activation of the steroidreceptor complex, its subsequent translocation to the nucleus, and specific binding to DNA, may be the site of a defect, possibly because of structural changes in the receptor molecule.

Interestingly, the son of the patient also showed a GR thermolability but an otherwise normal receptor status. There was, however, a minor difference in thermolability between mother and son, the latter showing a slightly less thermolabile receptor at temperatures ranging from $30^{\circ}$ to $40^{\circ} \mathrm{C}$. Clinically, this biochemical observation is supported by the fact that the son does have a tendency of fatigue but not to such an extent as his mother. Further more, lymphocytes from the controls were glucocorticoid responsive at $45^{\circ} \mathrm{C}$, as indicated by the suppressive action of dexamethasone on incorporation of $\left[{ }^{3} \mathrm{H}\right]$ thymidine into the cells, whereas no dexamethasone-induced decrease in $\left[{ }^{3} \mathrm{H}\right]$ thymidine incorporation in vitro was observed in lymphocytes from the two patients at this temperature; these results correlate well with the data from the GR thermolability assays.

Primary cortisol resistance or spontaneous hypercortisolism without Cushing's syndrome was first described by Vingerhoeds et al. in 1976 (1). These authors postulated a hyposensitivity to glucocorticoid action in a hypertensive, hypokalemic, but otherwise healthy male patient. The patient had a very high cortisol production rate with elevated plasma ACTH. Further studies on the cortisol resistance of this patient were published in 1982 by Chrousos et al. $(2,3)$, this time with regard to the ligand affinity of GR as well as to the GR number in white blood cells and fibroblasts. In contrast to our findings, these authors reported a decreased ligand affinity and a reduced receptor number, concluding that the cortisol resistance was due to an abnormal GR with decreased cortisol affinity.

Receptor-related glucocorticoid resistance because of "activation-labile" receptor complexes has been reported in human mutant lymphoma cell lines (30). Furthermore, therapy with pharmacologic glucocorticoid doses without the development of the stigmata of Cushing's syndrome has been linked with steroid resistance in receptor defective lymphocytes in patients with acute leukemia (31). Principally, it appears that alterations in the sensitivity to glucocorticoids can be traced to biochemical lesions at the receptor level $(4,32)$. In some cases, however, unresponsiveness to glucocorticoids occurs despite seemingly normal receptor functions and receptor concentration (33). Most of these observations, our own findings, and some other reports on steroid action in humans $(33,34)$ imply that the clinical manifestations of steroid resistance in general are rarely, if ever, due to the absence of a steroid hormonal receptor, but are probably due to changes in the receptor molecule that prevent its normal function.

The finding of a temperature instability of GR in lymphocytes and fibroblasts from our patients suggests the presence of a minor structural abnormality in the receptor molecule. Such a minor protein abnormality has been described for enzymes in bacterial mutants in which an elevation of temperature is associated with altered growth (35). Furthermore, in mutated mammalian cells structurally abnormal enzymes have been found to be responsible for the effects of elevated temperature on the functions of the cells $(36,37)$. An amino acid substitution at any position in the protein might lead to an alteration in the tertiary structure of the protein and consequently to altered biochemical properties.

Griffin (4) has described a thermolabile androgen receptor in cultured human fibroblasts from patients with testicular feminization. According to him, the degree of feminization was positively correlated to the biochemical alterations at the receptor level. In our case, the steady-state clinical picture was that of intermittent subtle glucocorticoid insufficiency-low weight, mild hypotension, and intermittent fatigue.

\section{Acknowledgments}

We wish to thank Leslie Morgan for her secretarial assistance.

This study was supported by a grant from the Swedish Medical Research Council (No. 13x-2819).

\section{References}

1. Vingerhoeds, A. C. M., J. H. H. Thijssen, and F. J. Schwarz. 1976. Spontaneous hypercortisolism without Cushing's syndrome. J. Clin. Endocrinol. Metab. 43:1128-1133.

2. Chrousos, G. P., A. Vingerhoeds, D. Brandon, C. Eil, M. Pegeat, M. DeVroede, D. L. Loriaux, and M. B. Lipsett. 1982. Primary cortisol resistance in man: a glucocorticoid receptor-mediated disease. J. Clin. Invest. 69:1261-1269.

3. Chrousos, G. P., A. C. M. Vingerhoeds, D. L. Loriaux, and M. B. Lipsett. 1983. Primary cortisol resistance: a family study. J. Clin. Endocrinol. Metab. 56:1243-1245.

4. Griffin, J. E. 1979. Testicular feminization associated with a thermolabile androgen receptor in cultured human fibroblasts. J. Clin. Invest. 64:1624-1631.

5. Seglen, P. O. 1976. Preparation of isolated rat liver cells. Methods Cell Biol. 13:29-83.

6. Hansson, L.-A., S. A. Gustafsson, J. Carlstedt-Duke, G. Garthon, G. Högberg, and J.-Å. Gustafsson. 1981. Quantitation of the cytosolic glucocorticoid receptor in human normal and neoplastic leukocytes using isoelectric focusing in polyacrylamide gel. J. Steroid Biochem. 14:757764.

7. Rosner, W., and S. T. Polimeni. 1978. An exchange assay for the cytoplasmic glucocorticoid receptor in the liver of the rat. Steroids. 31: 427-438. 
8. Scatchard, G. 1949. The aggregation of proteins for small molecules and ions. Ann. N.Y. Acad. Sci. 51:660-672.

9. Ham, R. G. 1980. Dermal fibroblasts. Methods Cell Biol. 21A: 255-276.

10. Wrange, Ö., and J.-Å. Gustafsson. 1978. Separation of the hormone- and DNA-binding sites of the hepatic glucocorticoid receptor by means of proteolysis. J. Biol. Chem. 253:856-865.

11. Wrange, Ö. 1979. A comparison of the glucocorticoid receptor in cytosol from rat liver and hippocampus. Biochim. Biophys. Acta. 582: 346-357.

12. Lowry, O. H., N. J. Rosebrough, A. L. Farr, and R. J. Randall. 1951. Protein measurement with the Folin phenol reagent. J. Biol. Chem. 193:265-275.

13. Alberts, B., and G. Herrick. 1971. DNA-cellulose chromatography. Methods Enzymol. 21:198-217.

14. Sherman, M. R., F. B. Tuazon, and L. K. Miller. 1980. Estrogen receptor cleavage and plasminogen activation by enzymes in human breast tumor cytosol. Endocrinology. 106:1715-1727.

15. Tanford, C., Y. Nozaki, J. A. Reynolds, and S. Makino. 1974. Molecular characterization of proteins in detergent solution. Biochemistry. 13:2369-2376.

16. DeMoor, P., P. Osinski, R. Deckx, and O. Steeno. 1965. The specificity of fluorimetric corticoid determinations. Clin. Chem. Acta. 9: 475-480.

17. Murphy, B. E. P. 1968. Clinical evaluation of urinary cortisol determinations by competitive protein-binding radioassay. J. Clin. Endocrinol. Metab. 28:343-348.

18. Thorén, M., M. Ajne, and K. Hall. 1981. Plasma pattern of immunoreactive ACTH in normal man and in patients with Nelson's syndrome. Acta Endocrinol. 96:15-23.

19. Boyd, G. W., A. R. Adamson, M. Arnold, V. H. T. James, and W. S. Peart. 1972. The role of angiotensin in the control of aldosterone in man. Clin. Sci. (Lond.). 42:91-107.

20. Reynolds, C., G. D. Molnar, and D. L. Horwitz. 1977. Abnormalities of endogenous glucagon and insulin in unstable diabetes. Diabetes. 26:36-45.

21. Kuzuya, T., A. Matsuda, and T. Saito. 1976. Human C-peptide immunoreactivity (CRP) in blood and urine: evaluation of a radioimmunoassay method and its clinical applications. Diabetologia. 12:511518.

22. Heynes, W. H., B. Van Baelen, and P. De Moor. 1967. Study of steroid-protein binding by means of competitive adsorption: application to cortisol binding in plasma. Clin. Chim. Acta. 18:361-370.

23. Horning, E. C., and W. J. A. Vandenheuvel. 1964. Gas-liquid chromatographic procedures for the separation, identification and estimation of steroids, alkaloids and sugars. In New Biochemical Separation, Vol. 2. A. T. James and L. J. Morns, editors. D. Van Nostrand Company, Ltd., London. 25-57.
24. Gold, E. M. 1980. Cushing's syndrome: a tripartite entity. In Neuroendocrinology. D. T. Krieger and J. C. Hughes, editors. Sinaner Associates, Inc., Sunderland, MA. 311-319.

25. Lippman, M., and R. Barr. 1977. Glucocorticoid receptors in purified subpopulations of human peripheral blood lymphocytes. J. Immunol. 118:1977-1981.

26. Atger, M., and E. Milgrom. 1976. DNA-cellulose chromatography. J. Biol. Chem. 251:4758-4762.

27. Carlstedt-Duke, J., S. Okret, Ö. Wrange, and J.-Å. Gustafsson. 1982. Immunochemical analysis of the glucocorticoid receptor: identification of a third domain separate from the steroid-binding and DNAbinding domains. Proc. Natl. Acad. Sci. USA. 79:4260-4264.

28. Sherman, M. R., M. C. Moran, F. B. Tuazon, and Y.-W. Stevens. 1983. Structure, dissociation, and proteolysis of mammalian steroid receptors: multiplicity of GR-forms and proteolytic enzymes in rat liver and kidney cytosols. J. Biol. Chem. 10366-10377.

29. Sherman, M. R., M. C. Moran, R. M. Neal, E.-M. Niu, and F. B. Tuazon. 1982. Characterization of molybdate-stabilized GR in healthy and malignant tissues. In Progress in Research and Clinical Applications of Corticosteroids. Proceedings of the Sixth Annual Clinical Symposium, February 20-22, 1981, Tallahassee, Florida. H. J. Lee and T. J. Fitzgerald, editors. Heyden, Philadelphia. 4-66.

30. Schmidt, T. J., J. M. Harmon, and E. B. Thompson. 1980. “Activation-labile" glucocorticoid receptor complexes of a steroid-resistant variant of CEM-C7 human lymphoid cells. Nature (Lond.). 286:507510.

31. McCaffrey, R., A. Lillquist, and R. Bell. 1982. Abnormal glucocorticoid receptors in acute leukemia cells. Blood. 59:393-400.

32. Stevens, J., Y.-W. Stevens, and H. Haubenststock. 1983. Molecular basis of glucocorticoid resistance in experimental and human leukemia. In Biochemical Actions of Hormones, Vol. 10. G. Litwack, editor. Academic Press, Inc., New York. 384-444.

33. Pike, J. W., S. Dokoh, M. R. Haussler, U. A. Lieberman, S. J. Marx, and C. Eil. 1984. Vitamin $D_{3}$-resistant fibroblasts have immunoassayable 1,25-dihydroxy-vitamin $\mathrm{D}_{3}$ receptors. Science (Wash. DC). 224:879-881.

34. Zawydiwski, R., J. M. Harmon, and E. B. Thompson. 1983. Glucocorticoid-resistant human acute lymphoblastic leukemic cell line with functional receptor. Cancer Res. 43:3865-3873.

35. Nakano, M. M., T. Sekiguchi, and M. Yamada. 1978. A mammalian cell mutant with temperature-sensitive thymidine kinase. Somatic Cell Genet. 4:169-178.

36. Edgar, R. S., and I. Lielausis. 1964. Temperature sensitive mutants of bacteriophage T4 D: their isolation and genetic characterization. Genetics. 49:649-662.

37. Tenner, A., J. Zieg, and I. E. Scheffler. 1977. Glucoprotein synthesis in a temperature-sensitive Chinese hamster cell cycle mutant. $J$. Cell. Physiol. 90:145-160. 